УДК 304.4

DOI https://doi.org/10.32837/yuv.v0i2.2147

\author{
Н. Грень, \\ кандидат юридичних наук, \\ суддя \\ Львівського окружного адміністративного суду
}

\title{
ПОРУШЕННЯ КОНСТИТУЦІЙНОГО ПРАВА НА ПРАЦЮ ЯК ПРОЯВ ДИСКРИМІНАЦІЇ ЗА ВІКОМ
}

Постановка проблеми. Право на працю - основоположне право людини. Стаття 6 Міжнародного пакту про економічні, соціальні та культурні права визначає право людини на працю як можливість заробляти собі на життя працею, яку вона вільно вибирає або на яку вільно погоджується [1]. Вагомість цього права проявляється через його основу для всього економічно-соціального добробуту людини, «наскільки є реальним право на працю, залежить реальність інших прав як соціально-економічного, так i політичного характеру» [2, с. 72].

Рівність має бути основним принципом реалізації права на працю, критерій професіоналізму - це первинна вимога для працівника. Проте нині можна констатувати, що сфера праці не позбавлена дискримінаційних ситуацій, до того ж підставами для дискримінації може бути будьяка особиста ознака людини, у тому числі особливо болісною є проблема дискримінації за віковою ознакою.

Стан дослідження. Питання дискримінації, іiі теоретико-правового розуміння $є$ предметом наукових дискусій увесь час. Дискримінаційні чинники можуть проявлятися у багатьох аспектах, серед них одним з найпоширеніших є вік. Проблему ейджизму у своїх працях порушували багато дослідників, серед них - Д. Бєлов, Ю. Бисага, Н. Бортник, І. Жаровська, Н. Ортинська, А. Комаренко та інші. Проте проблема дискримінації осіб старшої вікової групи у сфері праці залишається актуальною.
Метою статті $€$ аналіз проявів порушення конституційного права на працю як фактора дискримінації людини за віковою ознакою.

Виклад основних положень. Сучасні демографічні зрушення вимагають продовження трудового життя та політики продовження строку трудових відносин, збільшення віку виходу на пенсію в більшості промислово розвинутих країн. Вікова дискримінація (ейджизм) є поширеною і трапляється у всіх типах галузей та професій у всьому світі. Поширені помилки щодо «літніх робітників» включають ставлення як до таких, що мають усталені застарілі звички, технологічну необізнаність і відсутність енергії та гнучкості. Таке ставлення, очікування та уявлення про людей похилого віку не повинне існувати в професійній спільноті. Незалежно від віку та інших ознак до всіх людей слід ставитись 3 повагою та гідністю у цивілізованому суспільстві, що заохочує доктрину гуманізму та демократії.

Дискримінація на ринку праці отримала колосальне поширення. Насамперед це зумовлене зростанням рівня працівників старшої вікової групи. Кількість робітників старших за 50 років зросла на $80 \%$ за останні 20 років, це у чотири рази більше, ніж загалом зростання робочої сили [3].

Про зростання рівня констатують дослідження багатьох країн. Зокрема, науковий пошук таких країн, як Норвегія, Швеція, показав, що вікова дискримінація може спричинити негативні почуття, такі як марність, 
безсилля та зниження самооцінки. Це дослідження розробляє та затверджує шкалу моніторингу вікової дискримінації на робочому місці [4]. За результатами аналізу ситуації в Польщі фахівці констатують, що ейджизм може виступати хронічним стресовим фактором, що призводить як до погіршення фізичного здоров'я, так і до зменшення активності у здоровій поведінці [5].

Активізувалася проблема у зв'язку з економічними наслідками COVID-19, що відчувається в усьому світі, що з великою часткою ймовірності збільшить випадки дискримінації за віком. Вказане може включати роботодавців, які звільняють старших співробітників або не враховують кандидатів старшого віку у разі найму на роботу.

Також іноземні дослідження показують, що вікова дискримінація на ринку праці може набувати різних форм: жорсткої та м'якої, де жорсткий тип вікової дискримінації відображає заборонені законом типи поведінки та ті, які стосуються реальних рішень роботодавців, які можуть вплинути на кар'єрний розвиток працівника. М'яка дискримінація відповідає тим випадкам, які не вписані в правову систему як такі, що відбуваються переважно в міжособистісній сфері, але тим не менше можуть мати негативні наслідки. М'якої дискримінації зазнавали частіше (28,6\% респондентів), ніж жорсткої дискримінації $(15,7 \%)$, частіше серед жінок, осіб, які перебувають у нестабільній робочій ситуаціі, або жителів міських районів [6].

Звернемо увагу, що дискримінація може мати не тільки індивідуальну стигматизацію, а й негативно відображається на всій сфері відносин у суспільстві, негативно впливає на економічний складник держави. Опублікований ще у 2006 році зведений звіт організації економічного співробітництва та розвитку «Живи довше, працюй довше» зазначає, що в епоху стрімкого старіння населення зайнятість та соціальна політика, практика та відносини, що перешкоджають роботі у більш старшому віці, позбавлені актуальності та потребують капітального переосмислення. Вони не лише протидіють вибору літніми працівниками того, коли і як виходити на пенсію, але дорого обходяться для бізнесу, економіки та суспільства. Якщо нічого не робити для покращення перспектив працевлаштування для літніх працівників, кількість пенсіонерів на одного працівника в країнах ОЕСР подвоїться протягом наступних п'яти десятиліть. Це загрожує життєвому рівню та чинить величезний тиск на фінансування систем соціального захисту. Щоб допомогти вирішити ці грізні завдання, робота повинна бути більш привабливою для літніх працівників [7].

Більш сучасні дослідження, зокрема, вказують, що економіка США втратила додатковий прибуток 850 мільярдів доларів у 2018 році через вікову дискримінацію. Цей розрив може зрости до 3,9 трлн доларів у 2050 році [8].

До найпоширеніших наслідків дискримінації осіб старшої вікової групи належать:

- менш сприятливе ставлення до людей старшого віку в процесі найму та працевлаштування, що може призвести до вимушеного виходу на пенсію та неможливості змінити роботу;

- недостатня зайнятість осіб старшої вікової групи, наприклад неповна зайнятість;

- триваліші періоди безробіття.

За умови належної правової політики через заохочення літніх працівників залишатися активними на ринку праці уряд менше інвестує у соціальну допомогу для дорослих.

Протидія стереотипам, упередженням та віковій дискримінації у виробничому житті потребує широкого підходу. Факторами подолання дискримінації на робочому місці, на нашу думку, має стати комплекс гарантій, що вміщує чотири складники.

По-перше, належна державна політика у сфері праці, існування прямих нормативних заборон щодо 
недопущення дискримінації у сфері праці. 3 погляду формальної логіки в Україні належно забезпечене регулювання цієї сфери. Чинними є норми як міжнародного права, так і спеціальні правила поведінки, що визначені в кодифікованому трудовому акті. Базова Конвенція Міжнародної організації праці у сфері боротьби з дискримінацією 1958 р. № 111 [9] позиціонує дискримінацію як будьяке розрізнення, недопущення або перевагу за визначеними ознаками, що призводить до знищення або порушення рівності можливостей чи поводження в галузі праці та занять. Хоча цей документ не виокремлює вік як ознаку дискримінації, однак вказує на невичерпність ознак, тому попадає вік до категорії інших ознак. Більш широко це висвітлене в Кодексі законів про працю. Ст. $2^{-1}$ вказує на потребу рівності трудових прав громадян України, «забороняється будьяка дискримінація у сфері праці, зокрема, порушення принципу рівності прав і можливостей, пряме або непряме обмеження прав працівників» [10], у тому числі за ознакою віку. Ці зміни в КЗпП прийняті порівняно нещодавно, а саме у 2015 році.

Проте виключно правовим регулюванням проблему подолати неможливо, як вказує Урвін, «вікова дискримінація є багатогранною та складною, а політичні втручання мають лише часткові наслідки» [11].

Другим елементом подолання проблем дискримінації за віком мають бути інституційні, економічні та інші гарантії реалізації попередньо визначених нормативно правил поведінки. Гарантії реалізації права на працю створюють умови соціальної справедливості. «Справедливість реалізації праці проявляється не у популістських гаслах індивідів або їх груп, не у формалізмі соціальних конструкцій, що слугують для викривлення соціальної думки та спрямовані на політичні цілі, а в усвідомленому закріпленні у соціумі соціокультурних трудових гарантій. Саме їх наявність може убезпечити окрему людину праці від негативного політкон'юнктурного егоїстичного впливу та допомогти такій людині у пошуку шляхів соціального розвитку, допомогти інтегруватися у культурний простір трудового колективу» [12, с. 33].

I. Сахарук правильно констатує, що «на загальнодержавному рівні необхідно розробити та затвердити комплексні програми забезпечення трудової зайнятості молоді, а також осіб старших вікових груп, які б передбачили не лише основні напрями політики держави щодо додаткового захисту цих категорій працівників, але й переваги для роботодавців, що сприяють працевлаштуванню останніх. Вагоме значення має і розробка програм професійної орієнтації, підготовки і перепідготовки для молоді та осіб старших вікових груп (зокрема, літніх працівників та осіб похилого віку)» $[13$, с. 69].

По-третє, зміна ідеології та поведінки роботодавців може призвести до значного зменшення проблеми будьякої дискримінації, у тому числі за ознакою віку. Нині «концепція рівних можливостей еволюціонувала на соціальному та організаційному рівнях та оцінює роль управління різноманітністю у вирішенні сучасних питань» [14]. Створення інклюзивного робочого середовища є сучасною вимогою часу. Проте, на жаль, порушення відбувається доволі часто. Але дослідження Центру Трансамерики показують, що лише $39 \%$ роботодавців забезпечують гнучкість графіка роботи та роблять поступки за домовленістю [15].

Також керівний апарат підприємств та установ повинен проінформувати нижчий за підпорядкуванням ланцюжок менеджерів про наслідки дискримінації для фінансового стану компанії, а також для ї̈ репутаціі. «Будь-яка нерівність на робочому місці може призвести до відокремлення та ізоляції від основної робочої сили, i це може вплинути на ефективність 
працівників на робочому місці» [16]. Роботодавець має усвідомити, що вікова дискримінація прямо впливає на фінансовий прибуток підприємства.

По-четверте, подолання вікових стереотипів у суспільстві. Як вказує I. Жаровська, «формування громадянського суспільства та заохочення громадської активності визнане пріоритетним завданням суспільно-політичного розвитку» [17, с. 242]. Пріоритетним завданням $€$ руйнування вікових міфів через усвідомлення сильних сторін старших працівників, зокрема, таких як надійність, зрілість суджень, відсутність імпульсивності, своєчасність, сильна робоча етика та досвід. Соціально-культурний складник розвитку суспільної свідомості є особливо актуальним, проте, на жаль, болючим питанням. Дослідження, проведені в Новій Зеландіi,, продемонстрували неефективність законодавства у разі відсутності загального рівня толерантності, оскільки багато компаній продовжують порушувати закон, постійно акцентуючи увагу на віці під час процесу найму. Вікова інформація прямо чи опосередковано запитується у значного відсотка претендентів на роботу. Ці дані підкреслюють важливість соціально-економічного контексту, в якому приймається законодавство. «Як і у разі 3 неписаними нормами вплив закону в конкретному контексті неминуче обмежується глибоко вбудованим характером практики, особливо якщо примусове виконання є слабким» [18].

Загалом можемо констатувати, що з огляду на глибоко вкорінений характер вікової дискримінації у суспільстві, такий стан може призвести до негативних афективних реакцій окремих вікових груп, напруги у суспільстві та економічних криз.

Висновок. Вікова дискримінація $€$ поширеною i трапляється у всіх типах галузей та професій у всьому світі. Дискримінація у ставленні до робітників старшої вікової групи включає ставлення як до таких, що мають усталені застарілі звички, тех- нологічну необізнаність та відсутність енергії та гнучкості. Статистика доводить, що дискримінація на ринку праці отримала безпрецедентне поширення та активізувалася проблема у зв'язку з економічними наслідками COVID-19.

Констатовано, що дискримінація може мати не тільки індивідуальну стигматизацію, а й негативно відображається на всій сфері відносин у суспільстві, негативно впливає на економічний складник держави.

До найпоширеніших наслідків дискримінації осіб старшої вікової групи належать: менш сприятливе ставлення до людей старшого віку в процесі найму та працевлаштування, що може призвести до вимушеного виходу на пенсію та неможливості змінити роботу; недостатня зайнятість осіб старшої вікової групи, наприклад неповна зайнятість; триваліші періоди безробіття.

Протидія стереотипам, упередженням та віковій дискримінації у виробничому житті потребує широкого підходу. Факторами подолання дискримінації на робочому місці, на нашу думку, має стати комплекс гарантій, що вміщує чотири складники: нормативно визначену політику у сфері попередження та протидіï дискримінації; інституційні, економічні та інші гарантії реалізації норм права; зміна ідеології та поведінки роботодавців може призвести до значного зменшення проблеми будь-якої дискримінації, у тому числі за ознакою віку; подолання вікових стереотипів у суспільстві.

Статтю присвячено проблемі порушення конституційного права на працю як прояву дискримінациї за віком. Вікова дискримінація є поширеною $i$ трапляється y всіх munax галузей ma nрофесій у всьому світі. Дискримінація у ставленні до робітників старшої вікової групи включае ставлення як до таких, шо мають усталені застарілі звички, технологічну 
необізнаність та відсутність енергіi ma гнучкості. Широко репрезентована статистика багатьох держав (Норвегії, Польщі, США, Нової Зеландії, Швеціі) доводить, що дискримінація на ринку праці отримала безпреиедентне поширення та активізувалася проблема у зв'язку з економічними наслідками COVID-19.

Констатовано, що дискримінація може мати не тільки індивідуальну стигматизацію, а й негативно відображається на всій сфері відносин у суспільстві, негативно впливає на економічний складник держави.

До найпоширеніших наслідків дискримінації осіб старшої вікової групи належать: менш сприятливе ставлення до людей старшого віку в процесі найму та працевлаштування, що може призвести до вимушеного виходу на пенсію та неможливості змінити роботу; недостатня зайнятість осіб старшої вікової групи, наприклад неповна зайнятість; триваліші періоди безробіття.

Протидія стереотипам, упередженням та віковій дискримінаціï у виробничому житті потребуе широкого підходу. Факторами подолання дискримінаціі на робочому місиі, на нашу думку, має стати комплекс гарантій, що вміщуе чотири складники: нормативно визначену політику у сфері попередження та протидї дискримінаціі; інститущійні, економічні mа інші гарантї реалізації норм права; зміна ідеологї та поведінки роботодавців може призвести до значного зменшення проблеми будьякої дискримінації, у тому числі за ознакою віку; подолання вікових cmepeomunis y cycniльcmвi.

Пріоритетним завданням є руйнування вікових міфів через усвідомлення сильних сторін старших працівників, зокрема, таких як надійність, зрілість суджень, відсутність імпульсивності, сво- єчасність, сильна робоча етика ma досвід. Соціально-культурний складник розвитку суспільної свідомості $е$ особливо актуальним, проте, на жаль, болючим питанням.

Ключові слова: дискримінація, право на працю, гарантії, робітники старшого віку, ринок праці.

Gren N. Violation of the constitutional right to work as a manifestation of age discrimination

The article is devoted to the problem of violation of the constitutional right to work as a manifestation of age discrimination. Age discrimination is widespread and occurs in all types of industries and professions around the world. Discrimination against older workers includes treatment as having outdated habits, technological ignorance, and a lack of energy and flexibility. Widely represented statistics from many countries (Norway, Poland, the United States, New Zealand, Sweden) show that discrimination in the labour market has become unprecedented and has exacerbated the economic consequences of COVID-19.

It is stated that discrimination can have not only individual stigmatization, but also negatively affects the entire sphere of relations in society, negatively affects the economic component of the state.

The most common consequences of discrimination against older people include: less favourable treatment of older people in the recruitment and employment process, which can lead to forced retirement and inability to change jobs; insufficient employment of older age groups, such as underemployment; longer periods of unemployment.

Combating stereotypes, prejudices and age discrimination in working life requires a broad approach. In our opinion, the factors of overcoming discrimination in the workplace should be a set of guarantees, which contains 
four components: normatively defined policy in the field of prevention and counteraction to discrimination; institutional, economic and other guarantees of implementation of legal norms; changes in the ideology and behaviour of employers can significantly reduce the problem of any discrimination, including on the grounds of age; overcoming age stereotypes in society.

The priority is to break down ageold myths through awareness of the strengths of older employees, such as reliability, maturity of judgment, lack of impulsiveness, timeliness, strong work ethic, and experience. The socio-cultural component of the development of public consciousness is a particularly relevant, but unfortunately painful issue.

Key words: discrimination, right to work, guarantees, older workers, labour market.

\section{Література}

1. Міжнародний пакт про економічні, соиіальні та культурні права (OOH, 1966 p.). URL: https: / / zakon.rada.gov. ua/laws/show/995_042\#Text.

2. Комаренко А.М. Право на працю та проиесуальні особливості його захисту у суді. Вісник Одеського національного університету. Серія: Правознавство. 2016. T. 21, Bun. 2. C. 72-84.

3. Bureau of Labor Statistics, "Civilian labor force, by age, sex, race, and ethnicity". 2019. URL: https: / / wwr.bls.gov/emp/ tables / civilian-labor-force-summary.htm.

4. Furunes T., Mykletun R.J. Age discrimination in the workplace: Validation of the Nordic Age Discrimination Scale (NADS). Scandinavian Journal of Psychology. 2010. V. 51. P. 23-30.

5. Nelson T.D. Promoting healthy aging by confronting ageism. American Psychologist. 2016. V. 71. P. 276-282. DOI: 10.1037 /a0040221

6. Stypinska J., Turek K. Hard and soft age discrimination: the dual nature of workplace discrimination. Eur J Ageing. 2017. V. 14. P. 49-61. URL: https://doi. org / 10.1007/s10433-016-0407-y.

7. OECD, Live Longer, Work Longer - Ageing and Employment Policies. Paris : OECD Publishing, 2006. URL: https: / / www.oecd.org / employment / livelongerworklonger.htm.

8. AARP. The Economic Impact of Age Discrimination. How discriminating against older workers could cost the U.S. economy $\$ 850$ billion. URL: https: / / www.aarp.org / content / dam / aarp / research / surveys_statistics / econ/2020/impact-of-age-discrimination. doi.10.26419-2Fint.00042.003.pdf.

9. Про дискримінацію в галузі пращі та занять : Конвенція № 111 Міжнародної організаціі праці 1958 р. Конвенціі та рекомендації, ухвалені Міжнародною організацією праці. 1919-1964. Женева, 2001. T. 1. C. 648-651.

10. Кодекс законів про працю Украінни: затв. Законом № 322-VIII від 10.12.71 Відомості Верховної Ради. 1971, додаток до № $50, \mathrm{~cm}$. 375 .

11. Urwin Age Matters: A Review of Existing Survey Evidence. Employment Relations. Research Series 24. London : Department of Trade and Industry, 2004.

12. Вавженчук С.Я., Биркович O.I., Биркович Т.I. Право на працю як соиіокультурний феномен. Вісник Національної академії керівних кадрів культури $i$ мистецтв. 2019. № 2. С. 31-34.

13. Сахарук I.C. Дискримінація за ознакою віку у сфері праці. Вісник Запорізького національного університету. Юридичні науки. № 3, 2011. С. 63-70. С. 69.

14. Nachmias S., Aravopoulou E., Caven V. Diversity and Equality Issues in Modern Organisations / In: Nachmias S., Caven V. (eds). Inequality and Organizational Practice. Palgrave Explorations in Workplace Stigma. Palgrave Macmillan, Cham. 2019. URL: https://doi. org / 10.1007 /978-3-030-11647-7_2.

15. Transamerica Center for Retirement Studies, All About Retirement: An Employer Survey. 2017. URL: https: / / wwer. transamericacenter.org / docs / defaultsource / employer-research / tcrs2017_sr_ employer_research.pdf.

16. McFadden, Crowley-Henry. The International Journal of Human Resource Management. Early View. 2017. P. 1-26.

17. Жаровська I.м. Генезис ідеї відкритості влади. Форум права. 2009. Bun. 3. C. 242-246.

18. Wood G., Harcourt M., Harcourt S. The effects of age discrimination legislation on workplace practice: a New Zealand case study. Industrials Relation Journal. 2004. V. 35, Iss. 4. P. 359-371. DOI: https:// doi.org/10.1111/j.1468-2338.2004.00319.x. 